\section{Racism refuted}

Sir,--Many readers of Nature will have seen some of the extensive press coverage given to the campaign launched in the UK by the, avowedly racist National Front earlier this year to recruit members from schoolchildren and the young unemployed. This has included, according to the NF leadership, the distribution of up to 350,000 leaflets headed 'How to Spot a Red Teacher'. A central theme of this leaflet, and of a large supporting pamphlet on 'How to Combat Red Teachers' is the allegation that there are scientifically proven biological and psychological differences between races. As the leaflet puts it, under the heading 'The Racial Equality Lie'; "Tell the Red Teacher that top scientists like Jensen and Eysenck say this is rubbish. Scientists say that races are born different in all sorts of ways, especially in intelligence. This is because we inherit our abilities genetically".

The centrality of scientific racism to the NF's propaganda is indicated, too, by the comment of their national organiser, Martin Webster (who has publicly boasted of creating a "well-oiled Nazi machine" in Britain) that "the most important factor in the build-up of self-confidence amongst 'racists', and the collapse of morale among multi-racialists was the publication in 1969 by Professor Arthur Jensen in the Harvard Educational Review, (cited by Martin Walker in The National Front, Fontana, 1977, page 169)",

Professor Eysenck has given personal interviews to The Beacon, the newspaper of the now defunct, NF-related organisation, the National Party.

Many biologists and psychologists, myself included, have taken issue with Professor Eysenck and Jensen over their views on the genetic basis of intelligence and its class and race distribution. However, the claims made by the NF propaganda, in the names of Eysenck and Jensen, go far beyond anything that even they themselves have claimed. The openly racist intent of the NF, with its lineage stretching back to the 'Aryan biology' of the 1930s, must be repugnant to the majority of scientists and lay people alike. It would be a service to the cause of race relations in Britain, therefore, if Professors Eysenck and Jensen were to publicly and unequivocally dissociate themselves from the NF and its use of their names in its propaganda. Can I, through the courtesy of your columns, therefore, ask them to do so?

The Open University, UK. Steven Rose

SIR,-Professor Rose suggest that I have given personal interviews to The Beacon; this is untrue, although I am sure he made the allegation in good faith.

In a letter to The Times published earlier this year, I made it quite clear that I deplore the linking of my name and that of Professor Jensen, with the claims of the National Front for white supremacy and 'racism' generally. As I made clear in my original book on
Race, Intelligence and Education, and on numerous other occasions, I an absolutely opposed to any form of racism, and believe that the scientific evidencc unequivocally points to the need to treat each person individually in terms of his own personality, abilities, and achievements, not as a member of a racial group, or a particular sex, or class.

A denial of this proposition being the essence of racism, I believe that the large overlap in measures of ability always found between different races destroys, rather than supports, the basis of racism. It is source of considerable distress to me that the National Front has attempted to use my name and Professor Jensen's in their propaganda, and I am happy to take up Professor Rose's invitation to dissociate myself from the National Front and any other explicitly racist organisations. No-one familiar with Professor Jensen's or my own writings could possibly misinterpret our arguments about the mean differences between various racial and other groups with respect to intelligence as implying the kind of policies advocated by the National Front; I made this clear in my original publication, and have done so since.

University of London, UK H. J. EYSENCK

SIR,--Nothing has hindered progress toward a scientific understanding of the nature and causes of human differences in general mental ability individual differences and statistical differences between races than the gross and deliberate distortions of the available evidence by the extreme left and the extreme right. Both are equally guilty and both are equally offensive to all who seek a scientific understanding of human variation. Unfortunately, serious students of the subject are of ten forced to duck from the ideological cross fire.

Extremists of the left and right are alike in regard to the heredityenvironment controversy. They are both anxious to promote and to gain public acceptance of a particular dogmatic belief about the nature of racial differences, even when the scientific evidence is inadequate or contradictory. They both officially abhor a publicly agnostic stance regarding the scientifically still open questions. They both distrust the public with access to relevant knowledge and discussion concerning social class and racial differences. Most fundamentally, they both disdain human individuality. The leftists ideologically prefer to deny real differences in ability between individuals if the individuals are of different racial background; the rightists ideologically ignore differences between individuals if they are of the same racial background and treat human differences exclusively as differences between groups, obscuring the wide range of differences within each group and the great overlap of trait distributions among all human groups. Much overlap is found not just for mental ability, but for all important behavioural traits.

Recognition of individual differences and respect for individuality are the keystone of a free society, which both extremes of the political spectrum would destroy if they had their way. These ideologues have no real interest in scientific aspects of the 'nature-nuture', 'race difference', or 'IQ' controversies.

I have written a summary of my overall assessment of the issues in this complex field in "The Current Status of the IQ Controversy", an article recently published in the Australian Psychologist. In it, I stated:

"Research findings can have implications for social policies and practical applications only in relation to goals and values of the society. These implications do not flow directly from the scientific facts themselves... [T] he well established findings of a wide range of individual differences in IQ within all major racial populations and the great amount of overlap of their frequency distributions contradicts the racist philosophy that individuals of different races should be treated differently, one and all, only by reason of their racial differences. Those who would accord any treatment to individuals solely by virtue of their race will find no rational support from any of the scientific findings or theories of modern differential psychology. Man's genetic nature insures individuality, and any doctrine that is built on a denial of this fact is simply at odds with reality... My concept of justice requires that the fact of statistical differences between racial populations should not be permitted to influence the treatment accorded to individuals of any race--in education, employment, legal justice, and political and civil rights.

Righting the past wrongs of racial discrimination can be accomplished best... by prohibiting racial

discrimination in any form, by legal sanctions when necessary, and by seeking equal educational opportunities for members of minority groups who have been denied them in the past, so they can compete fairly for employment technical training, or higher education. without condescending dispensations. Since we are still far from a scientific consensus as to the causes of rraciall differences in educability, the only intellectually warranted official position of educators and governmental policy makers must be one of open agnosticism as to the causes, rather than the doctrinaire naive environmentalism that has so long prevailed as official policy. If scientific agnosticism is deemed unsatisfactory as a permanent state of affairs, and scientists are drawn to the challenge of reducing the heredity-. environment uncertainty, they have no choice but to continue the pursuit of normal science in the IQ controversy. In the history of intellectual conquest, agnosticism concerning socially important natural phenomena has always been a natural phenomena has always been a gives way either to dogmatic belief or to scientific knowledge."

University of California. ARTHur R. JENSEN

Berkeley, USA 